\title{
Populational density and harvest age of carrots for baby carrot manufacture
}

\author{
Adriano do N Simões ${ }^{1}$; Silvino I Moreira²; Franciscleudo B da Costa ${ }^{2}$; Alysson Roberto de Almeida ${ }^{3}$; Ri- \\ cardo HS Santos ${ }^{3}$; Rolf Puschmann ${ }^{2}$ \\ ${ }^{1}$ UFRPE-Unidade Adadêmica de Serra Talhada, 56900-000 Serra Talhada-PE; ${ }^{2}$ UFV-Depto Biologia Vegetal, 36570-000 Viçosa-MG; \\ ${ }^{3}$ UFV-Depto Fitotecnia; adriano@uast.ufrpe.br
}

\begin{abstract}
The quality of baby carrots may be associated to the standard of the raw material that in turn, may be influenced by agronomic practices. Thus, the effect of planting density and harvest age were assessed on physical and morphological characteristics, yield and end quality of intact and minimally processed carrots in the form of baby carrots. A randomized block experimental design was used with the density in the plots $(4 \times 20 \mathrm{~cm}$ and $4 \times 7.5 \mathrm{~cm})$ and the harvest age in the subplots $(50,57,64,71,78,85,92,99$ and 106 days), with five replications. The experimental unit consisted of 25 plants. The assessments of diameter, length, yield, secondary phloem translocation with the cambio and total carotenoids were decisive in selecting the carrot harvest age for baby carrot manufacture. Under the $4 \times 20 \mathrm{~cm}$ and $4 \times 7.5 \mathrm{~cm}$ adensed conditions, harvested between 85 and 92 days, carrot roots became thinner and more orange in color (with maximum carotenoid accumulation), larger and with satisfactory yields and therefore more acceptable for minimal processing in the form of baby carrots. Thus the decision of populational density associated to harvest age will depend on the market demand, on price, quality and other variables. The use of adensed cropping with early harvests may lead to obtain carrots and respective baby carrots that are more acceptable for commercialization.
\end{abstract}

Keywords: Daucus carota, quality, planting system, minimal processing.

\section{RESUMO}

Densidade populacional e idade de colheita de cenoura para produção de minicenoura

A qualidade final de minicenoura pode estar associada ao padrão da matéria prima, que, por sua vez, pode ser influenciada por práticas agronômicas. Por isso, objetivou-se avaliar o efeito da densidade de plantio e da idade de colheita em características físicas, morfológicas, no rendimento e na qualidade final de cenoura inteira e minimamente processada na forma de minicenoura. O delineamento experimental utilizado foi em blocos casualizado, tendo nas parcelas as densidades $(4 \times 20 \mathrm{~cm}$ e $4 \times 7,5 \mathrm{~cm})$ e nas subparcelas a idade de colheita $(50,57,64,71,78,85,92,99$ e 106 dias), com 5 repetições onde a unidade experimental foi composta por 25 plantas. As características de diâmetro, comprimento, rendimento, descolamento do floema secundário com o câmbio e carotenóides totais foram decisivos para selecionar a idade de colheita de cenoura destinada à fabricação de minicenoura. Nos dois adensamentos estudados, as raízes colhidas entre 85 e 92 dias, tornaram-se mais finas, de cor mais laranja (com máximo acúmulo de carotenóides), maiores, com rendimentos satisfatórios e, portanto, mais aceitáveis ao processamento mínimo na forma de minicenoura. Logo, a decisão de uso de densidade populacional associado à idade para se realizar a colheita, dependerá da exigência do mercado, do preço, qualidade e de outras variáveis. $\mathrm{O}$ uso de adensamentos de cultivo associados com colheitas antecipadas pode proporcionar a obtenção de cenoura e respectivas minicenouras mais aceitáveis para comercialização.

Palavras-chave: Daucus carota, qualidade, sistema de plantio, processamento mínimo.

(Recebido para publicação em 13 de fevereiro de 2009; aceito em 11 de janeiro de 2010) (Received on February 13, 2009; accepted on January 11, 2010)

A mong the minimally processed products, minicarrots, better known as baby carrots have been of special interest in Brazil (Lana et al., 2001; Moretti, 2004). This is associated with factors such as growth of the industry of minimal processing in the country and the simple use of primary matter for this purpose (Moretti et. al., 2004; Silva et al., 2003).

Baby carrots are peeled raw carrots that are selected, washed, cut into pieces of 5 to $6 \mathrm{~cm}$, lathed, disinfected with cold chlorinated water, centrifuged and packaged (Avena-Bustillos et al., 1994; Lana et al., 2001; Moretti, 2004; Simões et al., 2005a).

Baby carrots have been studied in the United States since the 1990s, principally regarding the causes of bleaching on the surface during their preservation (Bolin \& Huxoll, 1991; Bolin, 1992). In Brazil, in 2001, Embrapa began developing the technology of minimal processing of baby carrots, mainly with respect to the lathing step (Lana et al., 2001). In this period, the principal objective was to improve the carrots that showed a low market price in relation to other categories, that is, fine roots, where in some regions in the periods of greater supply they were discarded (Lana et al., 2001). On the other hand, Silva et al. (2001) and more recently Moreira et al. (2007) reported that root with large diameter should not be utilized in the 
minimal processing of baby carrots.

Agronomic management, such as variation of planting density and harvest age, can be an alternative for obtaining primary matter with distinct morphologic characteristics ideal for baby carrots (Moreira et al., 2006, 2007; Lazcano et al., 1998; Silva et al., 2003). In these studies, however, quality was not evaluated from the point of view of levels of total soluble solids and carotenoids. The latter comprises an important group of bioactive compounds with anticancer properties (Bendich \& Olson, 1989; Slattery et al., 2000; Gil et al., 2007). Besides, the peeling of the secondary phloem with the cambium and the yield after the lathing of baby carrots should be investigated, since there are few studies on this subject.

Various carrot cultivars have been studied for the purpose of their use in minimal processing, for example, Alvorada and Forto (Moretti et al., 2003; Silva et al., 2003), Esplanada (Vieira et al., 2005) and Caropak (Lazcano et al.,1998). The cultivar Esplanada and the imported hybrid Caropak, are materials suited for the production of baby carrots. However, Caropak appears to be poorly accepted by Brazilian producers, as their seeds are costly and not readily available on the market. Esplanada, because it is a new material on the market, can be found by chance, which is good reason for some resistance on the part of some growers for its planting. Thus, an alternative is to characterize and validate other national cultivars, with potential and wide utilization by these producers, as an alternative for their use in minimal processing in the form of baby carrots.

Thus, The objective of this work was to evaluate the effect of population density and harvest age in Forto carrots on physical and morphologic characteristics in the levels of total soluble solids and total carotenoids in carrots and/or baby carrots. In addition, yield of the final minimally processed product was determined.

\section{MATERIAL AND METHODS}

The experiments were carried out in the experimental field of the
Universidade Federal de Viçosa situated at $20^{\circ} 45^{\prime} \mathrm{S}, 42^{\circ} 51^{\prime} \mathrm{W}$ and an altitude of $651 \mathrm{~m}$ in the period of June 22 to September 28 of 2005 . The cultivar Forto was planted in beds $1 \mathrm{~m}$ wide and $0.2 \mathrm{~m}$ high.

Two population densities were evaluated: 4 x $20 \mathrm{~cm}$ (between plants and between rows) and $4 \times 7.5 \mathrm{~cm}$, corresponding to a population of 625,000 and 1,667,000 plants ha ${ }^{-1}$, respectively. The three central rows of the bed were considered parcels to be used for the first density, and the 11 central rows for the second density. The plants were irrigated by micro-spraying.

The soil showed, before planting, the following characteristics in the layer of 0 to $20 \mathrm{~cm}: \mathrm{pH}$ in $\mathrm{H}_{2} \mathrm{O}(1: 2.5)=6.0$; $\mathrm{P}($ Mehlich $\mathrm{I})=33.7 \mathrm{mg} \mathrm{dm}^{-3} ; \mathrm{K}=120$ $\mathrm{mg} \mathrm{dm}{ }^{-3} ; \mathrm{Al}^{3+}=0.0 \mathrm{cmol} \mathrm{dm}^{-3} ; \mathrm{H}^{+}+$ $\mathrm{Al}^{3+}=2.48 \mathrm{cmol}_{\mathrm{c}} \mathrm{dm}^{-3} ; \mathrm{Ca}^{+2}=2.6 \mathrm{cmol}_{\mathrm{c}}$ $\mathrm{dm}^{-3} ; \mathrm{Mg}^{2+}=0.6 \mathrm{cmol}_{\mathrm{c}} \mathrm{dm}^{-3}$. The organic compost was utilized as fertilizer, with the following characteristics: $45 \%$ organic matter; $\mathrm{C} / \mathrm{N}=14 / 1 ; \mathrm{pH}$ in $\mathrm{H}_{2} \mathrm{O}$ $=7.7 ; \mathrm{N}=2$ dag kg-1; $\mathrm{P}=1.88 \mathrm{dag} \mathrm{kg}^{-1}$; $\mathrm{K}=1.66 \mathrm{dag} \mathrm{kg}^{-1} ; \mathrm{Ca}=8.63 \mathrm{dag} \mathrm{kg}^{-1}$; $\mathrm{Mg}=0.49 \mathrm{dag} \mathrm{kg}^{-1} ; \mathrm{Cu}=43 \mathrm{mg} \mathrm{dm}^{-3}$; $\mathrm{Zn}=208 \mathrm{mg} \mathrm{dm}^{-3} ; \mathrm{Fe}=11.485 \mathrm{mg} \mathrm{dm}^{-3}$; $\mathrm{Mn}=742 \mathrm{mg} \mathrm{dm}^{-3}$; and $\mathrm{B}=23 \mathrm{mg}$ $\mathrm{dm}^{-3}$. Organic compost was applied at $10 \mathrm{t} \mathrm{ha}^{-1}$ at planting and later at $5 \mathrm{t} \mathrm{ha}^{-1}$ as side dressing, 30 days after planting, as recommended by Souza \& Resende (2003).

The emergence of the plantlets occurred between 7 and 10 days after planting and thinning was done between 33 and 37 days after planting. The beds were covered with dry grass to maintain moisture and for the initial control of weeds. Weeds were further controlled by manual clearing.

The first harvests were done at 50 or 64 days after seeding, and the subsequent ones occurred every seven days up to 99 or 106 days after seeding. All the plants in the designated rows in a linear $1 \mathrm{~m}$ of the bed were collected, equivalent to 60 plants for the density of $4 \times 20 \mathrm{~cm}$ and 220 plants for the density of $4 \times 7.5 \mathrm{~cm}$.

The following root measurements were obtained: upper diameter, at 1.5 $\mathrm{cm}$ from the upper end of the root; lower diameter, at $2 \mathrm{~cm}$ from the lower end; and middle diameter, in the middle region. Fresh weight and length were also quantified.

The cellular juice was extracted from $100 \mathrm{~g}$ of carrots, without periderm, triturated with the help of a food microprocesser and filtered through two layers of gauze, according to Simões et al. (2005c). Total soluble solids were determined using an Abbé table-type refractometer.

Total carotenoids were determined according to the method proposed by Lichtenthaler (1987). The carrots were extracted by the maceration of 2 $\mathrm{g}$ of whole tissue, without periderm, in a mortar containing $15 \mathrm{~mL}$ of $80 \%$ acetone. The extract was filtered through filter paper and the volume adjusted to $50 \mathrm{~mL}$ with $80 \%$ acetone in a volumetric flask. Total carotenoids were determined with the help of a spectrophotometer, where absorbance was read at 470, 462.3 and $446.8 \mathrm{~nm}$.

Carrots collected at 64 days of cultivation were submitted to minimal processing in the shape of baby carrots. Carrots were cut into pieces of $6.0 \mathrm{~cm}$ in length and lathed to the shape of cenouretes $^{\circledR}$ (Lana et al., 2001) with the help of two lathes, PCE SKYMSEN ${ }^{\circledR}$ and ETERNA ${ }^{\circledR}$, the first with abrasive sandpaper and the second with fine sandpaper, both during $1.0 \mathrm{~min}$ (Diniz et al., 2007).

The obtained baby carrots were submitted to an initial washing (rapid immersion in water at $5^{\circ} \mathrm{C}$ ), followed by immersion in water containing 200 $\mathrm{mg} \mathrm{L}^{-1}$ of chlorine (sodium dichloro-Striazinetrione dihydrate), for $10 \mathrm{~min}$. The final wash consisted of immersing the baby carrots in water containing 3 $\mathrm{mg} \mathrm{L} \mathrm{L}^{-1}$ of active chlorine, at $5^{\circ} \mathrm{C}$, for 10 $\min$. Next, they were centrifuged for 15 seconds at $800 \mathrm{~g}$ (Simões et al., 2005a), submitted to evaluations of diameter and weighed for quantification of yield.

The middle region of the baby carrots was utilized as the sampling site. The baby carrots were separated and classified subjectively into three classes, according to their diameter. Baby carrots with a diameter $<1.0 \mathrm{~cm}$ or $>2.5 \mathrm{~cm}$ were discarded because of being too fine or thick, respectively, and of little attractiveness, and they were not 
included in determining the yield. Baby carrots with diameters between 1.0 and $1.5 \mathrm{~cm}$ were considered optimal since they appeared fine, attractive and very acceptable; and those with a diameter of 1.51 to $2.0 \mathrm{~cm}$ were acceptable, while those between 2.1 and $2.5 \mathrm{~cm}$ less acceptable but still marketable.

The number of baby carrots where the secondary phloem was removed from the cambium, was determined and expressed as a percentage.

The yield was calculated, taking as a reference the weight of the primary matter and the weight of the baby carrots after centrifugation.

The experimental design utilized was randomized blocks, where the parcels were the densities $(4 \times 20 \mathrm{~cm}$ and $4 \times 7.5 \mathrm{~cm}$ ) and the subparcels the harvest time $(50,57,64,71,78$, 85, 92, 99 and 106 days), with 5 repetitions. Each experimental unit was composed of 25 carrots and/or baby carrots. The results were submitted to analysis of variance with the help of the program SAEG 9. In some cases, descriptive statistics were used followed by standard deviation of the mean and fitted regression equations.

\section{RESULTS AND DISCUSSION}

A significant interaction was considered at the $5 \%$ level of probability $(p<0.05)$ for the variables fresh weight and total soluble solids. For the other evaluations, only the harvest time had a significant influence. The data for all the treatments are presented in graphs to enrich the text.

The planting density of $4 \times 7.5 \mathrm{~cm}$ resulted in carrots of smaller diameters (at the end and middle region) in relation to the density of $4 \times 20 \mathrm{~cm}$, for all the harvesting days (Figure 1A, B and C). Finer carrots are generally obtained when they are grown densely (Bezerra Neto et al., 2005). Still, at both densities studied we observed that the later the harvest date, the greater the diameters were (Figure 1A, B and C).

With the population density of $4 \mathrm{x}$ $20 \mathrm{~cm}$, the harvests performed at 64 to 78 days yielded carrots of up to $2.3 \mathrm{~cm}$ of middle diameter (Figure 1C), which when minimally processed, resulted in baby carrots with a mean diameter of up to $2 \mathrm{~cm}$, (Figure 1D). When determining the proportion of baby carrots in each diameter class (Figure 2A and 2B), in the period between 64 and 78 days, 25 to $35 \%$ of the quantity of baby carrots obtained showed a diameter of 1 to 1.5 $\mathrm{cm}$, and 65 to $75 \%$, diameters of 1.51 to 2 cm (Figure 2A). Carrots collected at 85, 92 and 106 days of age, when submitted to minimal processing, resulted in 18 to $35 \%$ of baby carrots with a diameter of 1.51 to $2.0 \mathrm{~cm}$ and 65 to $85 \%$ of baby carrots with a diameter between 2.1 and $2.5 \mathrm{~cm}$ (Figure 2A). In this period, it was not possible to obtain finer baby carrots, with a diameter between 1.0 and $1.5 \mathrm{~cm}$ (Figure 2A). Thus, carrots cultivated at a population density of $4 \times 20 \mathrm{~cm}$ and harvested at up to 92 days, provided baby carrots classified between optimal, acceptable and barely acceptable based on diameter.

With a plant density of $4 \times 7.5 \mathrm{~cm}$, carrots were collected with up to 1.8 $\mathrm{cm}$ of middle diameter between 64 and 78 days (Figure 1C), obtaining after minimal processing, on average, baby carrots of up to $1.5 \mathrm{~cm}$ in diameter (Figure 1D). In the same period, 65 to $90 \%$ of the baby carrots showed a diameter between 1.0 and $1.5 \mathrm{~cm}$ and 10 to $35 \%$ with a diameter of 1.51 to $2 \mathrm{~cm}$ (Figure 2B). Carrots collected at 85, 92 and 106 days, when minimally processed, produced about 20, 20 and $10 \%$ of baby carrots with a diameter between 1.0 and $1.5 \mathrm{~cm}$, respectively, and 80,80 and $40 \%$ of baby carrots between 1.51 and $2.0 \mathrm{~cm}$, respectively (Figure 2B). Harvesting at 106 days resulted in about $50 \%$ of baby carrots with a diameter between 2.1 and 2.5 $\mathrm{cm}$ (Figure 2B). Therefore, carrots cultivated with a planting density of 4 $x 7.5 \mathrm{~cm}$ and harvested at up to 92 days, provided baby carrots classified between optimal and acceptable, and therefore finer in relation to a planting density of $4 \times 20 \mathrm{~cm}$.

Baby carrots with a diameter greater than $2.5 \mathrm{~cm}$ were not considered commercially acceptable, but possibly having other purposes, such as grated or cubed carrots or chips or sticks (Silva et al., 2003; Durango et al., 2006;
Moretti, 2006). Baby carrots with a diameter less than $1 \mathrm{~cm}$ can be utilized as non-processed baby carrots (Luz et al., 2006).

In the present work, even though the interaction between the treatments was not significant, the little difference in the diameters greatly influenced the acceptance or rejection of baby carrots. Therefore, diameter was an evaluation of great importance for characterizing the final quality of baby carrots.

The level of soluble solids varied little with planting density and age of the harvest (Figure 2C), with values close to $8 \%$ in practically all the collections, with the exception of the collection at 50 days (Figure $2 \mathrm{C}$ ). These values were superior to those found by Machado et al. (2003), which varied from 6.4 to $7.5 \%$, according to the spacing of the cultivation. These results indicate that the level of soluble solids was not decisive as an indicator of harvest in carrots, although it is considered a parameter of quality (Barros Junior et al., 2005).

Carotenoids accumulated between 50 and 92 days followed by stabilization, or even a small decline at 106 days (Figure 2D). The maximal accumulation of carotenoids occurred between 85 and 92 days (Figure 2D). Suslow et al. (1999) found a maximal accumulation of carotenoids in the carrot hybrid Caropak, between 90 and 97 days of cultivation, and thus, a finding similar to the results of the present work.

The orange color of carrot tissues is decisive in visual quality. The more orange the carrots, the greater the level of carotenoids is (Block, 1994; Silva, 2003; Surles, et al., 2004; Simões et al., 2005c). Carotenoids are most abundant in the tissues of carrots, with phloem tissue displaying the highest levels, followed by periderm and secondary xylem (Howard \& Dewi, 1996). The carotenoids and other lipophilic components can contribute $4.8 \%$ of the antioxidant capacity in fresh carrots (Wu et al., 2004; Podsedek, 2007). Therefore, the results obtained indicate that maximal accumulation of this constituent is at 85 days, at which time carrots have a more orange color, and thus, more recommended for harvest 


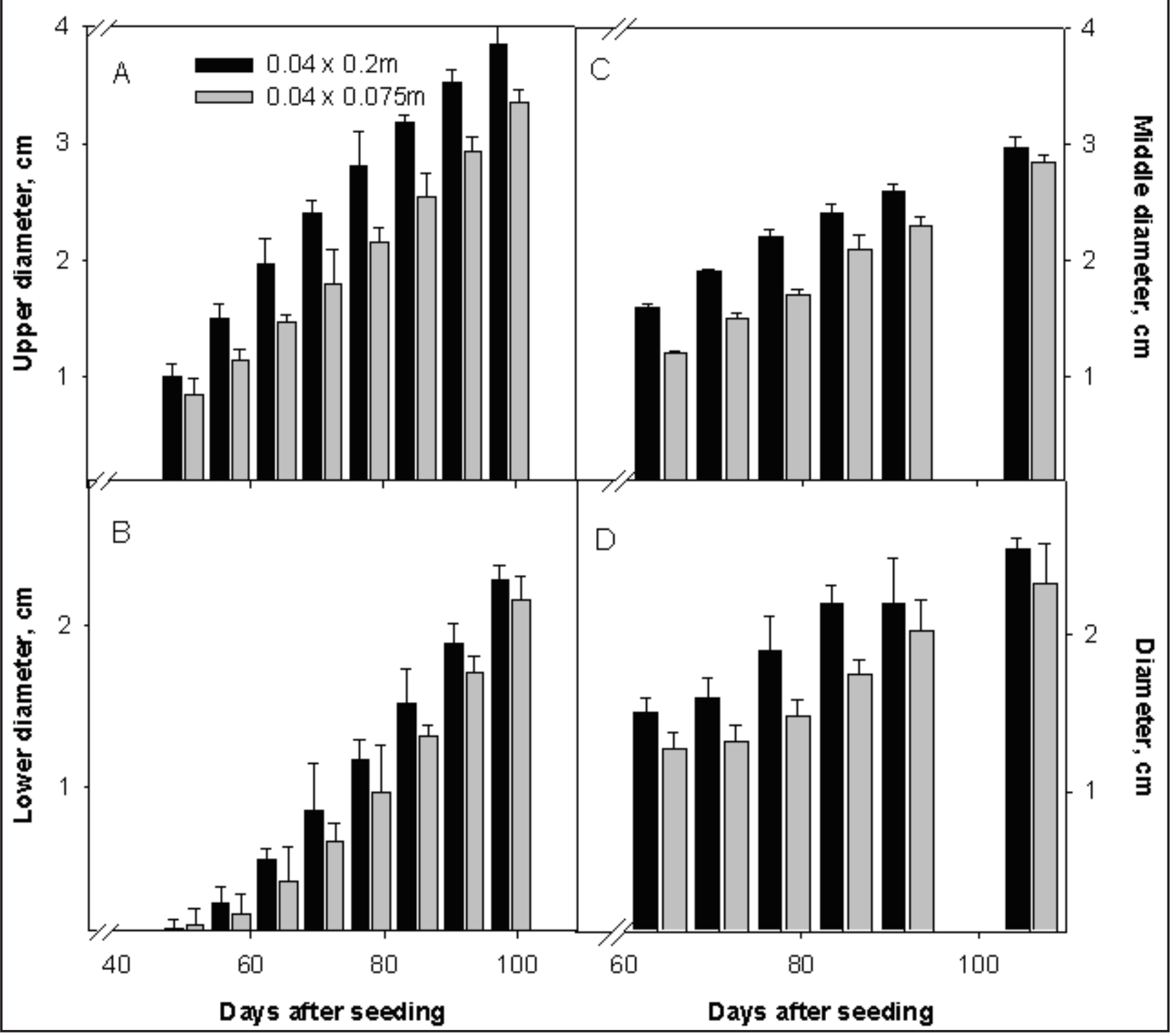

Figure 1. Diameters on the upper end (A), lower end (B) and middle region (C) of carrots, cv. Forto and of baby carrots (D), harvested on different ages after planting date, cultivated under the densities of 4 x 20 and 4 x $7.5 \mathrm{~cm}$. Vertical bars represent the average standard deviation (diâmetros (na extremidade superior [A], inferior [B] e na região mediana [C]) de cenouras cv. Forto e de minicenoura [D], colhidas em diferentes idades após a semeadura, cultivadas sob densidades de 4 x $20 \mathrm{~cm}$ e 4 x 7,5 cm. As barras verticais representam o desvio-padrão da média). Viçosa, UFV, 2005.

for the cv. Forto, regardless of the population density (Figure 2D).

The carrots planted at $4 \times 20 \mathrm{~cm}$ were the largest and weighed the most in relation to those cultivated under conditions of $4 \times 7.5 \mathrm{~cm}$ (Figure $3 \mathrm{~A}$ and B). Carrots collected between 64 and 92 days showed 11 to $15 \mathrm{~cm}$ in length for the density of $4 \times 20 \mathrm{~cm}$, and 9 to $13 \mathrm{~cm}$ for the density of $4 \times 75 \mathrm{~cm}$ (Figure 3A). Thus, with crowding of the cultivation, the carrots were smaller, as also found by Vieira \& Makishima (2000) and
Bezerra Neto et al. (2005).

The curve represented by the length showed characteristics similar to a logarithmic curve, indicating logarithmic growth of the root up to 85 days in relation to subsequent days (Figure $3 \mathrm{~A})$. On the other hand, the curve that represented fresh weight, showed characteristics of a double sigmoid, where it was fitted to a polynomial equation of the third degree with $\mathrm{R}^{2}$ $=0.98$, for the two densities studied (Figure 3B). Thus, the curve showed three distinct phases of behavior (Figure 3B), similar to sigmoidal curves that occur during the development of fruits (Serrano, 2007). The first phase of the curve was characterized by a slow increase in weight up to 64 days (Figure $3 \mathrm{~B})$. The second phase is represented by a rapid exponential increase, between 64 and 92 days (Figure 3B). This period coincided with the exponential increase in length and greater yields after the preparation of baby carrots, mainly with a planting density of $4 \times 7.5 \mathrm{~cm}$ 


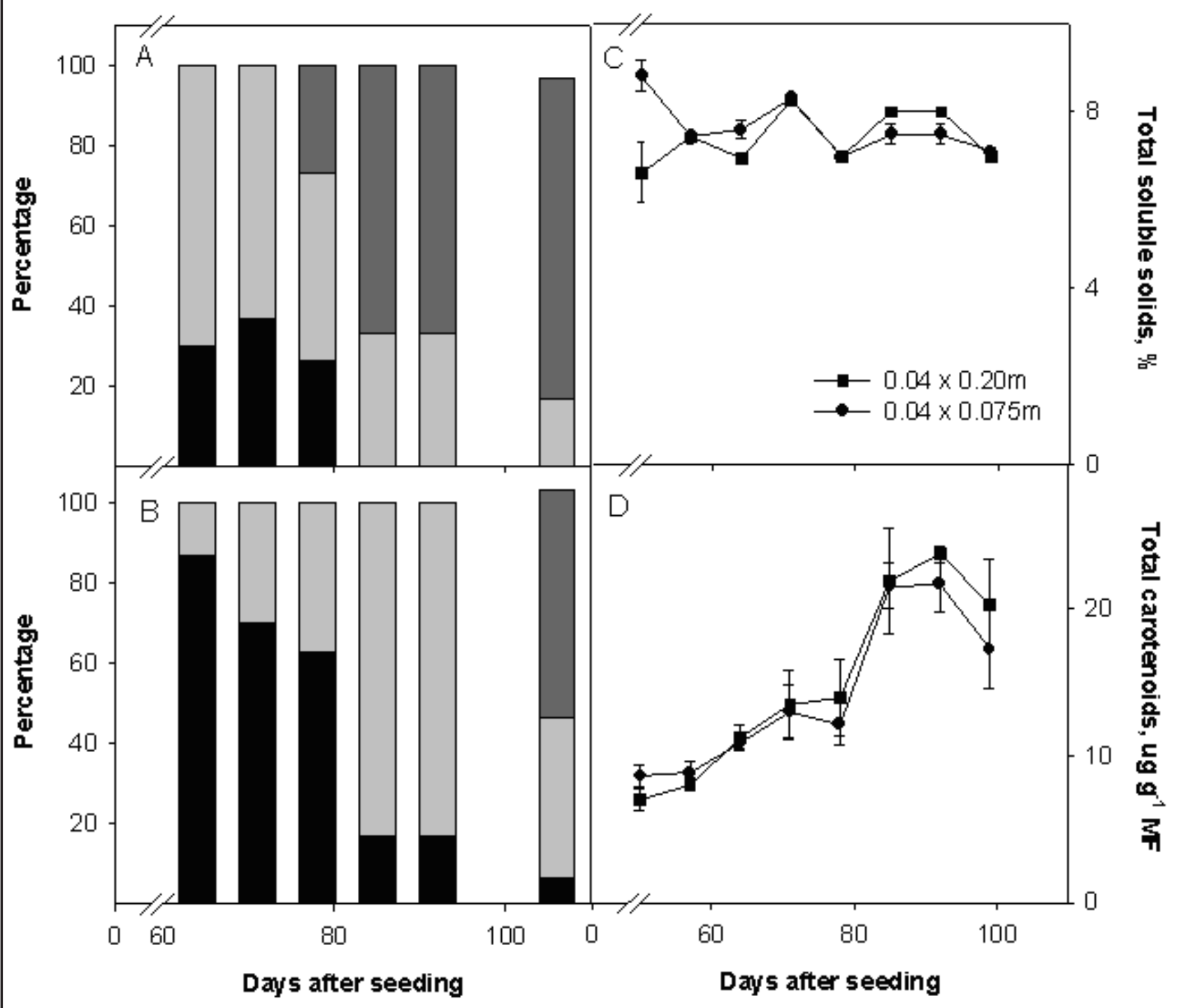

$1.0-1.5 \mathrm{~cm}$

$1.51-2.0 \mathrm{~cm}$

$2.1-2.5 \mathrm{~cm}$

Figure 2. Distribution of the diameter classes of baby carrots obtained from cv. Forto, cultivated under the densities of $4 \times 20 \mathrm{~cm}(\mathrm{~A})$ and under $4 \times 7.5 \mathrm{~cm}(\mathrm{~B})$, harvested on different ages after planting. Total soluble solids (C) and total carotenoids (D). Vertical bars represent the average standard deviation (distribuição de classes de diâmetros de minicenoura oriunda da cv. Forto, cultivadas nos adensamentos $4 \mathrm{x}$ $20 \mathrm{~cm}$ (A) e 4 x 7,5 cm (B), colhidas em diferentes idades após a semeadura. Sólidos solúveis totais (C) e carotenoides totais (D). As barras verticais representam o desvio-padrão da média). Viçosa, UFV, 2005.

(Figure 3A; Figure 4B). Therefore, the increments in yield can be related to the size of the carrots, suggesting the importance of the size of the root for the yield of baby carrots.

The third phase was characterized by a slow increase in weight, evident starting at 92 days (Figure 3B). In this period, there was practically little increase in size of the carrots (Figure $3 \mathrm{~A}$ and $\mathrm{B}$ ), and agroindustrial yields decreased (Figure 4A and B) with the two studied densities, probably because in this period, the carrots were overgrown and were not included in the determination of yield. These results suggest that length directly influences the quantitative results, as in the case of yield. On the other hand, diameter affects the qualitative results, as in the case of acceptability of the baby carrots.

A planting density of $4 \times 20 \mathrm{~cm}$, for collections of 64 to 92 days of age, provided carrots that when minimally processed resulted in yields between 45 and $60 \%$ (Figure $4 \mathrm{~A}$ ). In this period of 


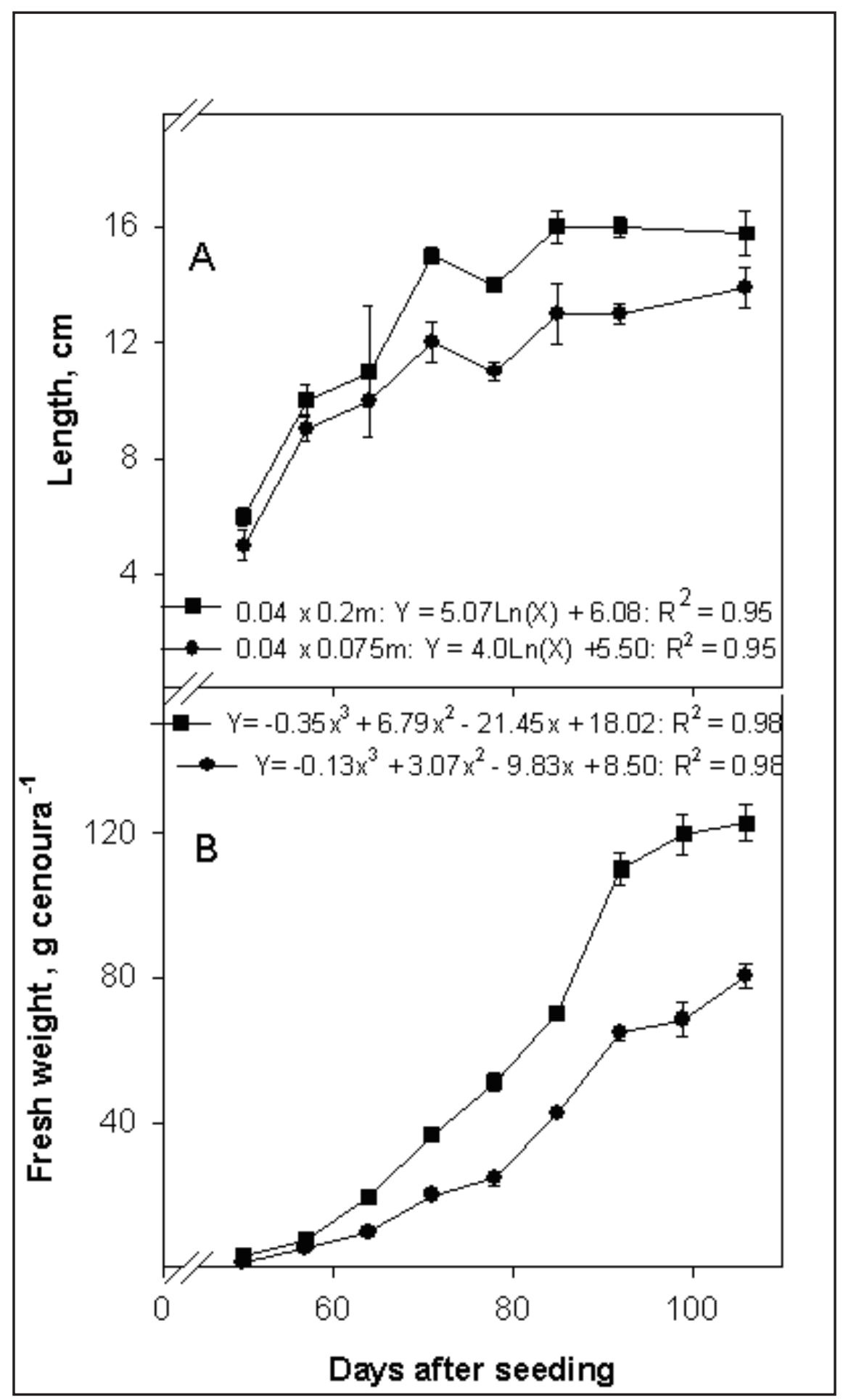

Figure 3. Length (A) and fresh mass (B) of carrots cv. Forto cultivated under the densities of $4 \times 20$ and $4 \times 7.5 \mathrm{~cm}$, harvested on different ages after planting date. Vertical bars represent the average standard deviation (domprimento (A) e Massa fresca (B) de cenoura cv. Forto, cultivadas dos adensamentos ( 4 × $20 \mathrm{~cm} \mathrm{e} 4$ x 7,5 cm); colhidas em distintas idades após a semeadura. As barras verticais representam o desvio-padrão da média). Viçosa, UFV, 2005.

evaluation, 35 to $50 \%$ were represented by cenouretes ${ }^{\circledR}$ and 5 to $20 \%$ catetos $^{\circledR}$ (Figure 4A). A density of $4 \times 7.5 \mathrm{~cm}$, harvested between 64 and 92 days, provided carrots that when minimally processed, produced yields between indicated a decrease in yield by $27 \%$ (Figure $4 \mathrm{~A}$ ), and $20 \%$ at a density of $4 \times 7.5 \mathrm{~cm}$ (Figure 4B). The main reasons for the decrease in yield were their middle diameters, over $2.5 \mathrm{~cm}$ and incidence of physical disturbance which was called detachment of the secondary phloem with the cambium, occurring immediately after lathing. Thus, baby carrots with these characteristics were not included in the estimation of yield.

The incidence of detachment of the secondary phloem with the cambium, occurred at a level of $10 \%$ for the density $4 \times 7.5 \mathrm{~cm}$ and $45 \%$ for the density of 4 x $20 \mathrm{~cm}$ at 106 days (data not shown). The lathing step appears to be the main initiator of detachment symptoms, probably due to the damage to which the carrot segments are submitted for some time in lathing with abarasive giratory movement. Besides, large carrots had these symptoms intensified. This indicates that at a particular age, cv. Forto carrots are not amenable to lathing and, consequently, to obtain mini carrots. The detachment of the secondary phloem with the cambium was also studied by Tatsumi et al. (1991) and Simões et al. (2005b). Their symptoms also tend to be aggravated during preservation, due to dehydration (Tatsumi et al., 1991). Thus, these symptoms are sufficient for the non-acceptance of baby carrots for market.

The low yield after the preparation of baby carrots, is one of the principal hindrances for the use of this product by small and medium-sized agroindustrial processors. The lathing step, can account for 37 to $50 \%$ of losses in agroindustrial yield, depending on the time of lathing (Diniz et al., 2007). In publications reported by Embrapa, the global yield was about 30 to $40 \%$ (Moretti, 2006; Vieira et al., 2005). However, the aggregated value for this type of product (baby carrots), compensates for its low yield, because it can often cost as much as three times more, in relation to other forms of minimally processed carrots.

The agroindustrial yields found in this work were up to $70 \%$, that is, almost two times more in relation to previous works. Therefore, besides the cultivar, various other factors can contribute to yield, such as the planting density 


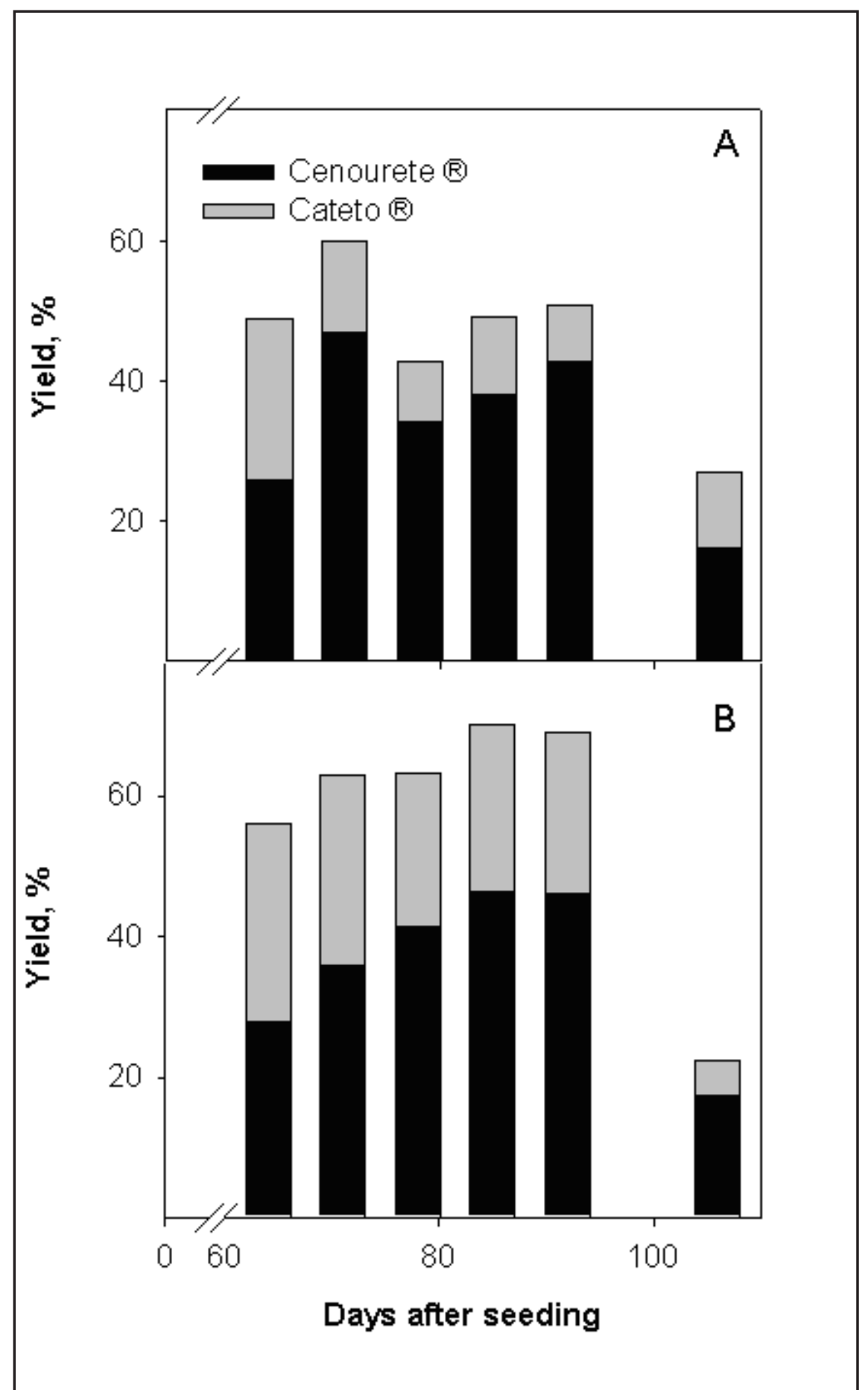

Figure 4. Yield of baby carrots obtained from cv. Forto, planted under the densities of 4 x 20 (A) and 4 x $7.5 \mathrm{~cm}$ (B), from carrots harvested on different ages after planting date. Rendimentos após a fabricação de minicenouras oriundas de cenouras da cv. Forto cultivadas a 4 × $20 \mathrm{~cm}$ (A) e 4 × 7,5 cm (B), a partir de cenouras colhidas em distintos dias após a semeadura. Viçosa, UFV, 2005.

and harvest age. Thus, the increase in population density associated to anticipated harvests can provide better morphologic standards of carrots for use in minimal processing of baby carrots, with satisfactory agroindustrial yields.

The carrot cultivar Forto, planted at a density of $4 \times 20 \mathrm{~cm}$ and $4 \times 7.5$ $\mathrm{cm}$ and harvested between 85 and 92 days, provided fine and larger carrots, with maximal carotenoids, thus more orange colored, with satisfactory yields, and thus more acceptable to minimal processing in the form of baby carrots.
The evaluations of diameter, length, yield, detachment of the secondary phloem with the cambium and total carotenoids were decisive for selecting the harvest age of the carrots destined for preparation of baby carrots.

The decision to use population densities and harvest age, will depend on market demand, such as price and others, to offer baby carrots of finer standards and consequently better quality.

\section{ACKNOWLEDGEMENTS}

The authors thank CNPq, CAPES and FAPEMIG for financial support.

\section{REFERENCES}

AVENA-BUSTILLOS RJ; CISNEROSZEVALLOS LA; KROCHTA, JM; SALTVEIT, ME. 1994. Application of casein-lipid edible film emulsions to reduce white blush on minimally processed carrots. Postharvest Biology. Technology. 4: 319-329.

BARROS JÚNIOR APB; BEZERRA NETO F; SILVA EO; NEGREIROS MZ; OLIVEIRA EQ; SILVEIRA LM; LIMA JSS; FREITAS KKC. 2005. Qualidade de raízes de cenoura em sistemas consorciados com alface sob diferentes densidades populacionais. Horticultura Brasileira 23: 290-293.

BENDICH AE; OLSON JA. 1989. Biological actions of carotenoids. The Federation of American Society for Experimental Biology 3: 1927-1932.

BEZERRANETOF; JÚNIORAPB; NEGREIROS MZ; OLIVEIRA EQ; SILVEIRA LM; CÂMARA MJT. 2005. Associação de densidades populacionais de cenoura e alface no desempenho agronômico da cenoura em cultivo consorciado em faixa. Horticultura Brasileira 23: 233-237.

BLOCK G. 1994. Nutrient sources of provitamin A carotenoid in the American diet. American. Journal Epidemiological 139: 290-293.

BOLIN HR; HUXOLL CC. 1991. Control of minimally processed carrot (Daucus carota) surface discoloration caused by abrasion peeling. Journal of Food Science 56: 416418.

BOLIN HR. 1992. Retardation of surface lignification on fresh peeled carrots. Journal Food Processing and Preservation 16: 99103.

DINIZ LT; PUSCHMANN R; SIMÕES AN; COSTA FB; MORAES FFF; TAKAYAMA AA; FREITAS MA. 2007. Tempo de Torneamento de cenoura para obtenção de minicenoura. In: XVI Simpósio de Iniciação Cientifica, VI SIMPÓS-Mostra Científica da Pós-Graduação, IV Simpósio de Extensão Rural, Viçosa, MG.

DURANGO AM; SOARES NFF; ANDRADE NJ. 2006. Microbiological evaluation of an edible 
antimicrobial coating on minimally processed carrots. Food Control. 17: 336-341.

GIL MI; ALLENDE A; MARTINEZ-SANCHES

A. 2007. Factores que afectan al contenido de compuestos bioactivos en alimentos de IV Gama. V Congreso Iberoamericano de Tecnología Poscosecha y Agro exportaciones. Universidad Politecnica de Cartagena CDRom. p. 725-761.

HOWARD LR; DEWI T. 1996. Minimal processing and edible coating effects on composition and sensory quality of mini-peeled carrots. Journal Food Science 61: 643-651.

LANA MM; VIEIRA JV; SILVA JBC; LIMA DB. 2001. Cenourete e Catetinho: minicenouras brasileiras. Horticultura Brasileira 19: 376379.

LAZCANO CA; DANIELLO FJ; PIKE LM; MILLER ME; BRAMDENBERG L; BAKER LR. 1998. Seed lines, population density, and root size at harvest affect quality and yield of cut-and-pell baby carrots. HortScience 33: 972-975.

LITCHTHENTHALER HK. 1987. Chlorophylls and carotenoids: pigments of photosynthetic biomembranes. In: PACKER L; DOUCE R. (eds) Methods Enzymology 148: 350-382.

LUZ JMQ; CARVALHO JOM; COELHO CMB; CARVALHO TD. 2006. Produção de minicenouras não processadas em função de diferentes cultivares e espaçamentos. Horticultura Brasileira 24: 221-223.

MACHADO CMM; CARVALHO PGB; VIEIRA JV; SILVA JBC. 2003. Influência do espaçamento na quantidade de açúcares solúveis e sólidos solúveis totais em cenoura Horticultura Brasileira, Brasília, Disponível em http:/horticiencia.com.br/anais Acesso em 25 de jan. 2003. 10:55.

MOREIRA SI; SIMÕES AN; COSTA FB; FARIA LC; SOUZA DD; OLIVEIRA FC; PUSCHMANN R. 2006. Idade de colheita de cenouras, rendimento e qualidade de minicenouras. IV Encontro Nacional sobre Processamento Mínimo de Frutas e Hortaliças. I Simpósio Íbero-Americano de Vegetais Frescos Cortados. São Pedro-SP, Brasil.

MOREIRA SI; PUSCHMANN R; SIMÕES AN; COSTA FB; DINIZ LT; MORAES FFF; FARIA LC; SOUZA DD; OLIVEIRA FC. 2007. Características físico-químicas de cenouras híbrido Caropak e rendimento na fabricação de minicenouras. XVI Simpósio de iniciação científica VI Simpós-Mostra científica da pós-graduação IV Simpósio de extensão universitária, Viçosa-MG, Brasil.

MORETTI CL; BERG FLN; MATTOS LM; DURIGAN MFB; CARON VC; KLUGE RA; JACOMINO AP. 2003. Temperatura de armazenamento e embalagem determinam o comportamento fisiológico e a qualidade de minicenouras. In: Congresso Brasileiro de Olericultura, 43. Recife. Anais. CD-ROM. Recife-PE, Brasil.

MORETTI CL. 2004. Processamento mínimo de minicenouras. III Encontro Nacional sobre Processamento Minimo de Frutas e Hortaliças. p. 91-95.

MORETTI CL. 2006. Aproveitamento de resíduos do processamento mínimo de frutas e hortaliças. In: IV Encontro Nacional sobre Processamento Mínimo de Frutas e Hortaliças, I Simpósio Íbero Americano de vegetais frescos cortados. Anais. São Pedro, Brasil.

PODSEDEK A. 2007. Natural antioxidants and antioxidant capacity of Brassica vegetables: A review. Lebensmittel-Weissens und Technologie. 40: 1-11.

SALGADO AS; GUERRA JGM; ALAMEIDA DL; RIBEIRO RLD; ESPÍNDOLA JAA; SALGADO JAA. 2006. Consórcios alfacecenoura e alface-rabanete sob manejo orgânico. Pesquisa Agropecuária Brasileira. Brasília. 4: 1141-1147.

SERRANO LAL. 2007. Fenologia e produção da goiabeira Paluma, submetida a diferentes épocas e intensidades de poda de frutificação. UENF, RJ. 100p. (Tese doutorado).

SILVA JBC; VIEIRA JV; LIMA MM; LIMA DB. 2001. Produção de cenourete e catetinho. Brasília, DF: Embrapa Hortaliças. 12 p. (Embrapa Hortaliças. Circular Técnica, 28).

SILVA VA. 2003. Fisiologia de Cenoura Minimamente Processada. Viçosa: UFV, 78p. (Tese mestrado).

SILVA JBC VIEIRA JV; MACHADO CMM; LIMA GB. 2003. Rendimento das cultivares de cenoura Alvorada e Nantes cultivadas sob diferentes espaçamentos. In.: Congresso Brasileiro de Olericultura. CD-Rom. BrasíliaDF, Brasil.

SIMÕES AN; MOREIRA SI; SANTOS RHS; PUSCHMANN R; FIALHO CA; BARBOSA RL; BARRELLA TP; SIQUEIRA RG. 2005a. Centrifugação de mini cenouras em centrífuga doméstica. In: $45^{\circ}$ Congresso Brasileiro de Olericultura. CD-ROM. Fortaleza-CE,
Brasil.

SIMÕES AN; MOREIRA SI; PUSCHMANN R; COSTA FB; FERREIRA RF; BORDÃO LL. 2005. Caracterização de cultivares de cenouras durante a fabricação de mini cenouras. In: $X$ Congresso Brasileiro de Fisiologia Vegetal, Recife-PE.

SIMÕES AN; MOREIRA SI; COSTA FB; PUSCHMAN R; SANTOS RHS; SIQUEIRA RG; BARRELA TP. 2005c. Teores de sólidos solúveis e carotenóides em cultivares de cenouras cultivadas organicamente. $45^{\circ}$ Congresso Brasileiro de Olericultura. Fortaleza-CE.

SLATTERY ML; BENSON J; CURTIN KMAK; SCHAEFFER D; POTTER JD. 2000. Carotenoids and colon cancer. American Journal Clinical Nutrition 71: 572-582.

SOUZA JL; REZENDE P. 2003. Manual de Horticultura Orgânica. Viçosa: Aprenda Fácil. 564p.

SURLES RL; WENG N; SIMON PWE; TANUMIHARDJO SA. 2004. Carotenoid profilies and consumer sensory evaluation of specialty carrots (Daucus carota, L.) of various colors. Journal Agricutural Food Chemistry 52: 3417-3421.

SUSLOW TV; WU J; PEISER G. 1999. Characterization of carotenoid composition of carrots cffected by "Light Root Syndorme". Perishables Handling Quarterly Issue. 100: 11-14.

VIEIRA JV; MAKISHIMA N. 2000. Cultivo da Cenoura. Brasília: EMBRAPA-CNPH, (EMBRAPA-CNPH. Sistema de Produção, 2.

VIEIRA JV; SILVA JBC; CHARCHAR JM; RESENDE FV; FONSECA MEN; CARVALHO AM; MACHADO CMM. 2005. Esplanada: cultivar de cenoura de verão para fins de processamento. Horticultura Brasileira 23: $851-852$

TATSUMI Y; WATADA AE; WERGIN WP. 1991. Scanning electron microscopy of carrot stick surface to determined cause of white translucent appearance. Journal of Food Science 56: 1357-1359.

WU X; BEECHER G; HOLDER J; HAYTOWITZ D; GERBHADT E; PRIOR R. 2004. Lopophilic and hydrophilic antioxidant capacities of common foods in the U.S. Journal Agricultural Food Chemistry 52: 4026-4037. 